\title{
A Fatherhood Faith-Based Values Intervention programme for incarcerated fathers at the Potchefstroom Remand Detention Facility: A narrative approach
}

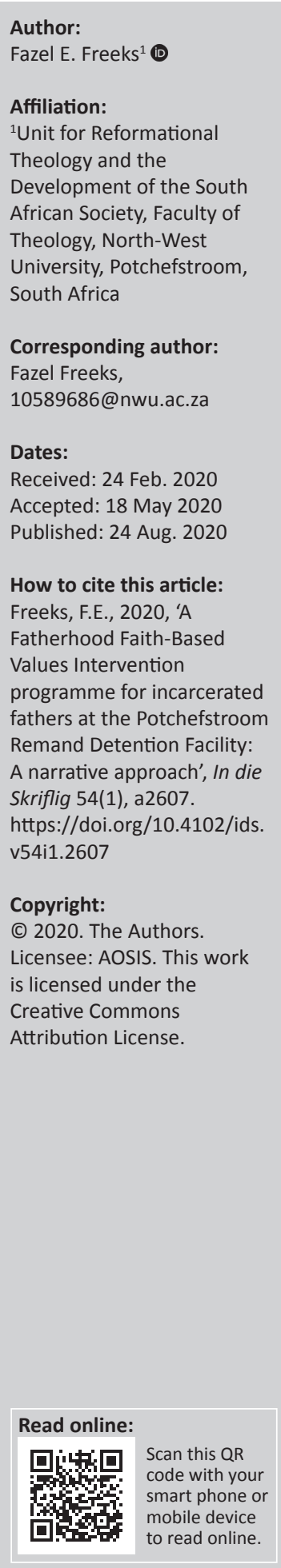

This article provides a reflective discussion of and narrative approach to incarcerated fathers based on the attendees of a Fatherhood Faith-Based Values Intervention programme at the Potchefstroom Remand Detention Facility. It is important to note that one-third of South African inmates are between the ages of 18 and 25 years - hence the reason why the majority of intervention and community engagement programmes at correctional services take place amongst the youth age group. The Department of Correctional Services reported in 2011 that South Africa had 159265 incarcerated inmates at the time, of whom 110905 were sentenced offenders and 48360 were awaiting trial. In 2013, the World Incarcerated Brief reported that South Africa had the largest incarcerated population in Africa and the ninth largest in the world. Seventeen-year-olds comprised 53000 of this number and were guilty of committing serious crimes. These numbers increased tremendously over the years. According to the former South African Minister of Correctional Services, Mr Sibusiso Ndebele, in 2013,30\% of inmates were awaiting trial, and most of them were young black men. He also indicated that, although 23000 inmates were being released each year, 25000 were introduced into the correctional services system. South Africa currently has overcrowded places of incarceration even though the president of South Africa, Mr Cyril Ramaphosa, granted special remission to 14647 offenders in 2019. Incarcerated fathers are traumatised and affected by these places of captivity, even when they are on parole or released from detention. The effect of incarceration on fathers is a serious concern in South African society and challenge to the researcher who studies the fatherhood phenomenon and the dilemma of father absence.

Keywords: fathers; fatherhood; faith-based; values; programme; inmates; correctional services.

\section{Rationale}

The Department of Correctional Services reported in 2011 that South Africa had 159265 incarcerated inmates, of whom 110905 were sentenced offenders and 48360 were awaiting trial. In 2013, the World Incarceration Brief reported that South Africa had the largest incarceration population in Africa and the ninth largest in the world (News24 2013). Furthermore, Makou, Skosana and Hopkins (2017) noted that South Africa had 236 operational places of incarceration as of March 2016 that catered for inmates. In 2013, the South African Correctional Services Minister at the time, Sibusiso Ndebele, reported that $30 \%$ of inmates were awaiting trial, and most of them were young black men (News24 2013).

Furthermore, 53000 inmates as young as 17 years of age were found guilty of committing serious crimes because they did not complete their education, which left them illiterate and homeless. The former minister (Sibusiso Ndebele) also indicated that although 23000 inmates were released each year, another 25000 entered the correctional services system, placing a serious financial burden on the Department of Correctional Services. In that year, it cost the department approximately R8000 per month to keep an inmate in incarceration (News24 2013). The report also indicated that 64959 offenders were not incarcerated at that time. Of these, 48323 were on parole, 14917 had been provisionally released and 1719 were awaiting trial (News24 2013).

The above-mentioned statistics are not only a grave concern for the South African government but also an enormous challenge for the researcher who studies the fatherhood phenomenon and the 
dilemmas created by father absence. Hence, there is a necessity for the Fatherhood Faith-Based Values Intervention programme for the Potchefstroom Remand Detention Facility.

\section{Introduction and problem statement}

This article proposes the Fatherhood Faith-Based Values Intervention programme as a contribution to help fight the social issue of absent fathers and, in this case, incarcerated fathers (Freeks 2011a, 2011b ${ }^{1}$ ). The significance of this intervention programme has been used to train and equip incarcerated fathers at the Potchefstroom Remand Detention Facility.

As mentioned, the programme addresses a common social issue: father absence ${ }^{2}$ in the South African landscape. Father absenteeism is a phenomenon that not only occurs in local South African communities but also worldwide (Dobbs 2013:2; Freeks 2013:3; Popenoe 1996; Staples 1999; Williams 2014). Although father absenteeism is a dilemma not unique to South Africa, it is one of South Africa's major challenges. Moreover, father absence is a societal malice that challenges the nation to the heart of its communities (Salami \& Okeke 2018:2). Father absence and fatherlessness are a serious concern, which Carstens (2014) identifies in his research as the fourth-ranked problem in the world. Research has consistently confirmed that the notion of fatherhood and the issue of father absence are crucial factors in society (Freeks 2019:1-3; Londt, Kock \& John-Lanba 2017:154-155; Matlakala et al. 2019:6-7; Salami \& Okeke 2018:4-7). Notwithstanding the changing world, fathers still play a unique role in the development of their children's behaviour, life choices, relationships and self-esteem (Vaughan 2010; Waresak 2016a, 2016b).

Fathers who are involved in family life and connected with family members are more likely to be non-violent; unlikely to abuse drugs; and are more likely to be content, healthier and more productive at work. (Levtov et al. 2015:5-14). However, these findings cannot be generalised to all families. Some research has shown that cases of abuse may occur even if a father is connected with and involved in family life and not prone to substance abuse or violence is involved in family life and connected and is not prone to substance abuse or violence (Brelsford 2011; cf. Londt et al. 2017:151-152).

Towards the academic debate in terms of fatherhood, it is evident that fathers have increasingly become the subject of research in the last few decades; however, there is much to learn and discover about fathers and their roles. Most studies have come up with father involvement, father attachments

1.Fatherhood and father absenteeism are the author's speciality fields and main research focus areas. He uses self-referencing to build arguments, introduce new knowledge, provide input, make contributions and suggest solutions to a societal problem, namely father absence.

2.The author of this article published numerous articles papers nationally and internationally on this phenomenal issue. His research focus or niche area is on family studies, especially and specifically on the fundamental role of the father. and fatherhood models (e.g. Cabrera 2020; Meyer 2018; PekelUludagli 2019; Peyper, De Klerk \& Spies 2015; Sieber 2008; Wood \& Brownhill 2018, to name but a few) from the psychological, social and physical sciences in terms of the human father, but a few studies have shown the significant effect of the Fatherhood of God. Popenoe (1996) is a great example in this regard. My initial argument in terms of the concept and definition is that fatherhood stems from the Bible and it is important to comprehend the concept from a biblical perspective. I am of the opinion that this biblical way of giving expression to fatherhood has, however, declined and become extinct. This biblical way should be reinstated. The revelation of God through Scripture as Father through his son Jesus Christ and his saving grace not only provides knowledge and information, but also helps, advises and gives insights in terms of fatherhood, broken families and father absence.

\section{Research objective}

The objective of this study was to reflect on and discuss a fatherhood faith-based values intervention programme run amongst incarcerated fathers at a correctional facility in Potchefstroom, South Africa.

\section{Research design}

This article followed a reflective discussion and narrative approach where intervention was conducted through a community engagement programme with incarcerated fathers. I present a narrative approach based on practical theological research. This approach evolved through an effective interchange between research, theory, training, equipping, live experience and reflection. The narrative approach emerged as a discipline within the scope of my own broader research (Freeks 2011a), and I place the narrative approach within the framework of fatherhood. This approach aims to reflect on the inmates' emotions, lived experiences, feelings, behaviour, growth, resilience and spiritual life.

The context of the reflective discussion and narrative approach was the Potchefstroom Correctional Services (now Potchefstroom Remand Detention Facility). Furthermore, the reflective discussion also includes faith-based values as part of the programme developed and compiled, using research conducted by myself (Freeks 2011b) about the fundamental role of the father (Freeks 2011a).

This programme was run with inmates (incarcerated fathers) over a period of 5 years (2015-2019). The North-West University (NWU) was and still is in partnership with the Potchefstroom Remand Detention Facility. Through community engagement, the Head of Correctional Centre (HCC) raised an urgent request for the university to train and equip incarcerated fathers - most of whom are young fathers. Incarcerated fathers participated in this training and equipping programme because of their interest and desire to become better fathers by the time they would be on parole or released from the place of incarceration. 


\section{The White Paper on Corrections}

The White Paper on Corrections in South Africa, Chapter 3 (3.3.7), states (Department of Correctional Services 2004):

The creation of an environment in which offenders are encouraged to discard negative and destructive values and replace them with positive and constructive values as the core business of the Department of Correctional Services. (p. 31)

The central focus of the White Paper on Corrections in South Africa is the urgency to focus correctional activities on the rehabilitation of inmates. The Department of Correctional Services shares this urgency with society in general. The White Paper also emphasises the importance of identifying correction as a societal responsibility to be undertaken as a departmental duty to achieve a rehabilitation goal (Department of Correctional Services 2005).

The White Paper focuses on societal responsibility in the rehabilitation of offenders and on the re-integration of exoffenders into society. Relatedly, the Fatherhood Faith-Based Values Intervention programme suggests and provides possible solutions to incarcerated fathers and to the societal problem of father absenteeism.

\section{The Potchefstroom Remand Detention Facility}

The Potchefstroom Remand Detention Facility was previously known as the Potchefstroom Correctional Services. It was not an easy path to establish the place of incarceration for male inmates in Potchefstroom. The first building was built in 1847 - a one-room building with walls of hay and a roof of reeds to serve as a place of incarceration. The second was built in 1864, but it was a half-done, rotten affair. The third was built between 1874 and 1876, but was damaged in 1880-1881 during the battle between the English and the Afrikaners (or Boers). In 1967, a fourth place of incarceration was erected that accommodated approximately 390 inmates. These places of incarceration were used to help build a larger place to meet the needs of the growing incarcerated population. In 1977, the fifth place of incarceration was vacated and today it serves as command offices. Later, all the other places of incarceration were relocated to the new place, which is also referred to as the sixth place of incarceration. The Potchefstroom CorrectionalServices, better known today as the Potchefstroom Remand Detention Facility, now accommodates around 1800 awaiting-trial detainees, 170 sentenced men and 80 sentenced women, and approximately 2050 inmates, both men and women (Veltman 2018). In terms of the current population, the statistics of black people are roughly $75 \%$, people of mixed race $20 \%$ and white people $5 \%$ at the Potchefstroom Remand Detention Facility (Veltman 2020).

\section{The Fatherhood Faith-Based Values Intervention programme}

The Fatherhood Faith-Based Values Intervention programme offers a solution to train and equip incarcerated men, in the form of a facilitator's manual, in this context, based on the attendees' needs (inmates who are fathers) (cf. Freeks 2011c). The programme is aligned with and supports the purposes of the White Paper on Corrections in South Africa because it has the potential to make a positive impact by instilling faith-based values in incarcerated fathers and to positively steer them away from negative and destructive behaviour.

\section{Aims of the Fatherhood Faith-Based Values Intervention programme}

The programme aims to address father absenteeism, fatherlessness, uninvolvement, neglect of children and family dilemmas. It offers guidelines and possible solutions to restore the crucial role of the father within a family context and to build better relationships in families through the leadership of the father and mother. The programme proposes the opportunity for incarcerated fathers to make informed, quality decisions whilst still in places of incarceration awaiting release or parole. Incarcerated fathers are encouraged to become more involved in the lives of their family members, especially their children (Families South Africa [FAMSA] 2014).

Furthermore, the programme strives to enable fathers to connect with other fathers about their role, to feel empowered, to help identify a common purpose in terms of their families and to create a space within which new possibilities for incarcerated fathers can emerge (Freeks 2011c).

\section{The draft, initial commencement training, layout and themes of the Fatherhood Faith-Based Values Intervention programme}

The programme was first drafted, compiled and structured in 2011 (cf. Freeks 2011c) and officially started in 2015 at the Potchefstroom Remand Detention Facility. The layout of the programme consists of a concrete manual and workbook with practical activities in which fathers (inmates) actively participate when conducting the training sessions. The programme has seven themes which are constructive, relevant and practical. These themes include:

- the concept of fathering

- the importance of self-image for fathers

- the approach of character versus career

- how to overcome labelling

- how to handle disappointments

- the father as developer

- how to becoming fully you (Freeks 2011c).

The programme was specifically developed to be used in the field of community engagement. It was later amended and adapted after further studies into fatherhood, father absenteeism, uninvolved fathers and the fundamental role of the father within the family context (Freeks 2013, 
2016a，2016b，2017a，2017b，2017c，2018a，2018b，2019; cf. Freeks \& Lotter 2009, 2014; Freeks, Greef \& Lotter 2015a; Freeks, Strydom \& Bartlett 2015b).

The programme is one of the strengths and core responsibilities of the research because the main aim thereof is to train and equip fathers in general, including fathers in places of incarceration, to restore the indispensable role of the father within the family context.

\section{The importance of faith-based values (or Christian values) in this fatherhood training and empowering programme}

Why should we enable incarcerated fathers with faith-based values (Christian values)? Although there are other values besides faith-based values, for me, it is vital to point out that the Bible provides us with a clear description of the origin of values. Christian values are set within a value system that holds the Bible as the authoritative Word of God, and a faith that springs from the belief in the Trinity (cf. Van Wyk 1996:533). Joubert (1986) stated the importance of Christian values (or faith-based values) three decades ago as follows:

The realization that values play a basic role in people's lives and even the society is now more than a far-flung notion. Many believe and others defend the notion that values are the most important and eventual principles of social norm activities. Values represent a social holiness, and it is this holiness that causes society to question values. (p. 2)

Furthermore, I am firmly of the opinion that people's values should flow from their beliefs and world views. An individual can get his or her world- and life-view from religion or a belief system. What is a world view in this context? It is the comprehensive framework of one's basic beliefs about everything (cf. Theron 2008).

Values as a world view should be those highest priorities in life that cannot be ignored. The world view of Christians is shaped and tested according to the Bible (Van der Walt 2008:2-3), and Christians benefit from any intervention in which their world view could be shaped by values and tested against the Bible (cf. Nimmo 2007:43-44; Vorster 2004:87, 179). An applicable example is the fruit of the Holy Spirit, namely, love, joy, peace, patience, kindness, goodness, faithfulness, gentleness and self-control. These can be regarded as the Christian (or faith-based) values (cf. Cunningham 2008:158-159; Van der Walt 2010:215; Vorster 2007:221; 2008a:200; see also Gl 5:22; Phlp 4:8).

Faith-based values can be understood as a world view, and a person's choices can be evaluated as right or wrong with good or bad consequences in which his or her life can be influenced either positively or negatively by these choices. Faith-based values do not exist in isolation - they have significance that is based on God's ordinations for life (Banner 2009:11-14; Van der Walt 2008:2, 2010:45).
Faith-based values can be meaningful, not only for one's personal life, but also for the whole of life, including one's marriage, family, business, education, professional life and more (Van der Walt 2008:2).

Vorster (2008b:60-61) refers to these values as a world view of ethics and norms. With that said, a Christian world view can be instrumental in bringing about transformation and change in the way a person lives his or her life through faith-based values. God governs his creation through the principles of values, and the spiritual laws are binding for all created beings, especially humankind. A human, in fact, is a spiritual being with spiritual values (cf. Van der Walt 1999:330).

In this context, spiritual values are described as a feeling of being influenced by or of being in communication with something holy or sacred. Examples of spiritual values are love, respect, honour, worship, prayer, sanctification, obedience, practising religion, faith, assurance, trust, friendship, devotion, surrender, integrity, forgiveness, justice, fairness, caring, goodness, non-violence, generosity, courage, hope, self-control, temperance, practical wisdom, human dignity, salvation, honesty, kindness, responsibility, duty, freedom, deliverance, ways of living, assurance or certainty and redemption (Brown 2007:216; Cunningham 2008:54-57; cf. Lepholletse 2008:27).

Faith-based values have specific indicators, including religious practices, faith, worship, prayer, sanctification, obedience, friendship, love, respect, honour, assurance in faith, human dignity, obedience, deliverance, diligence, justice, kindness, generosity, self-control, righteousness, honesty, caution, gentleness, integrity, humility, purity and patience. These indicators can be highly beneficial to the incarcerated father. I am attracted to these values because they appeal to the Christian viewpoint that I adhere to.

To summarise, faith-based values serve as guidelines for behaviour and criteria for evaluating people, in this case, the incarcerated fathers.

Values give meaning and direction to a person's existence, and values are contained in aspects such as attitude and belief. Faith-based values can decidedly be embraced and prioritised by the incarcerated father. If faith-based values can improve the lives of incarcerated fathers and their families, then these values are worth striving for.

\section{Intervention, training and equipping}

The basis of the fatherhood intervention focused mainly on my study about the father as mentor in the transmission of values: a pastoral-theological study (cf. Freeks 2011a), and it also formed part of the Fatherhood Faith-Based Values Intervention programme that was launched for incarcerated fathers in 2015. 


\section{The aim and implementation of the planned intervention}

The planned intervention was developed with the aim of training and equipping South African incarcerated fathers to fulfil their roles as fathers within their family contexts. The intervention was planned by FAMSA in collaboration with my research on fatherhood to address the challenges of father absence and fatherlessness among incarcerated fathers (cf. Freeks 2011a.). The planning was under discussion for 5 months, and and it deals with all the critical aspects needed to implement needed to implement a timely, practical and relevant fatherhood faith-based values and community engagement programme as a possible solution to the problematic issues of father absence and fatherlessness.

This faith-based values intervention programme officially started with an intervention to 15 incarcerated fathers at the Potchefstroom Remand Detention Facility in 2015. From 2015 to 2018, approximately 250 incarcerated fathers were trained and equipped through the Fatherhood Faith-Based Values and Intervention programme.

\section{Reflection on the impact of the Fatherhood Faith-Based Values Intervention programme}

As mentioned earlier, the participants in the training and equipping sessions were approximately 250 male inmates (fathers) at the Potchefstroom Remand Detention Facility. The findings in terms of the Fatherhood Faith-Based Values Intervention Training and Equipping Programme were based on resilience building, and it resulted in four specific areas, namely, the emotions of fathers before the programme, the emotions of fathers after the programme, the areas of growth after the programme and fathers' spiritual life after the fatherhood programme. Before the presentation of the fatherhood programme, fathers indicated that they felt very depressed. This problem was further explored in group discussions, and reasons included that the fathers had no hope, no support, no values, a lack of skills development and poor training. Fathers also felt inferior owing to family rejection, degrading life in prison and poor living conditions. After the fatherhood programme, it was significant to see that fathers indicated that they felt more positive and that they were more hopeful compared to before. Furthermore, fathers indicated that they feel happier than before, owing to follow-up emotional support that built positive faith-based values and relationships between the presenter, fathers, facilitators and the staff of the Correctional Services. Owing to the positive relationships that fathers built amongst themselves, it was remarkable to see the positivity of fathers towards the programme, facilitators and correctional staff. Furthermore, growth was evident in terms of own identity, and that most of them take responsibility for their own life, actions and choices. Moreover, it was noteworthy that fathers indicated their positive growth in terms of their spiritual life and adhering to faith-based values. The Fatherhood
Faith-Based Values Intervention programme indicated that it was important for fathers to do introspection in their own lives and many of them were motivated and willing to do so. This behaviour is, however, evident and can be seen from the participation in spiritual activities, such as Bible study, prayer groups and spiritual services on specific Sundays. Fathers also indicated that they feel part of a spiritual family, and that they have a deep desire to be transformed, guided by faithbased values. Unfortunately, a smaller group of inmates indicated a lack of a sense of responsibility, which is, in fact, needed in fatherhood.

The impact incarcerated fathers can have, especially on the development of their children is profound and can last for a lifetime. A father's emotional engagement with his children can lead to multiple positive outcomes and long-term investments when the foundation is built on trust, respect, connection and engagement.

\section{Preliminary inferences}

Preliminary investigations have led me as the researcher to infer the following about the Fatherhood Faith-Based Values Intervention Programme:

- It contains unique opportunities to invest in the spirituality and quality of life of incarcerated fathers.

- It is an ideal programme to change and improve the lives of incarcerated fathers.

- It has the potential to impact incarcerated fathers positively and ensure a value-driven society.

- It provides follow-up support through mentoring when inmates are on parole or released from their place of incarceration.

- It contributes tremendously to the Potchefstroom Remand Detention Facility because it assists and supports the rehabilitation programme requirements contained in the White Paper on Corrections. (The White Paper's view on corrections as a societal responsibility and not just as crime prevention encourages communities to get involved, collaborate and interact with incarcerated fathers in order to facilitate their integration into the community. This includes the involvement of community-based organisations, non-government organisations, faith-based organisations and institutions, such as the NWU with its Fatherhood Faith-based Values programme).

- It should be considered for future research at the Potchefstroom Remand Detention Facility as a proposed solution to the pervasive problem of father absenteeism in South Africa.

\section{Recommendations}

The study of incarcerated fathers has led to the following recommendations:

- The Fatherhood Faith-Based Values Intervention programme was implemented mainly because of NWU's collaboration with the Detention Facility, as well as the fervent presentation of the programme itself, and the meticulous preparation beforehand. It is vital to first gain 
permission to access a correctional facility before any programme, workshop, intervention or research can be conducted in the facility.

- The White Paper on Corrections in South Africa should endeavour to implement mentoring sessions for incarcerated fathers, especially those on parole.

- The proper fathering skills training and training aids should be embedded in the content of the Fatherhood Faith-Based Values Intervention programme, specifically adapted for incarcerated men, so as to train and equip them for their crucial task of being faith-based, valuedriven fathers to their families.

- Faith-based values are the driving force behind the programme and are gaining traction in this article. Therefore, this programme should be rolled out to other correctional facilities in the country.

\section{Conclusion}

Not everyone supports a faith-based values intervention programme for incarcerated fathers, but new dynamics of fatherhood are being studied and, in this context, the importance of values is displayed. When incarcerated fathers were asked about their overall view of a faith-based values programme, the accustomed response was a desire and hope that incarcerated fathers could be better, effective and active fathers to their families after the training. The participation of incarcerated fathers in the programme and their perceptions of fatherhood, in the context of faith-based values, made it possible for them to contribute their views. Family scientists have reflected that men's contribution to and participation in family life is crucial in any society. Research on and studies of incarcerated men have also motivated an interest currently in the dilemma of father absenteeism in society.

\section{Acknowledgement}

\section{Competing interest}

The author declares that he has no financial or personal relationships that may have inappropriately influenced him in writing this article.

\section{Author contributions}

I declare that I am the sole author of this research article.

\section{Ethical consideration}

This article followed all ethical standards for a research without direct contact with human or animal subjects.

\section{Funding Information}

This research received no specific grant from any funding agency in the public, commercial or not-for-profit sectors.

\section{Data availability statement}

Data sharing is not applicable to this article as no new data were created or analysed in this study.

\section{Disclaimer}

The views and opinions expressed in this article are those of the author and do not necessarily reflect the official policy or position of any affiliated agency of the author.

\section{References}

Banner, M., 2009, Christian ethics: A brief history, John Wiley \& Sons Ltd., Hoboken, NJ.

Brelsford, G.M., 2011, 'Divine alliances to handle family conflict: Theistic mediation and triangulation in father-child relationships', Psychology of Religion and Spirituality 3(4), 285-297. https://doi.org/10.1037/a0021602

Brown, A., 2007, 'Christianity', in P. Morgan \& C.A. Lawton (eds.), Ethical issues in six religious traditions, 2nd ed., pp. 216-219, Edinburgh University Press Ltd, Edinburgh.

Cabrera, N., 2020, 'Father involvement, father-child relationship, and attachment in the early years', Attachment and Human Development 22(1), 134-138 https://doi. org/10.1080/14616734.2019.1589070

Carstens, C., 2014, The world needs a father: A trainers' guide, Paarl Media Printers, Cape Town.

Cunningham, D., 2008, Christian ethics: The end of the law, Routledge, London.

Department of Correctional Services, 2004, White Paper on corrections in South Africa, draft 4, Government Printers, Pretoria.

Department of Correctional Services, 2005, White Paper on corrections in South Africa, Government Printers, Pretoria.

Dobbs, P., 2013, 'The impact of fatherlessness on the way one relates to God as father', MTh dissertation, University of Otago, Dunedin, viewed n.d., from https:// hdl.handle.net/10523/4672

Families South Africa (FAMSA), 2014, Annual general meeting report, pp. 1-22, FAMSA, Potchefstroom.

Freeks, F.E., 2011a, 'The role of the father as mentor in the transmission of values: A pastoral-theological study', PhD thesis, North-West University, Potchefstroom.

Freeks, F.E., 2011b, 'Waardes en die noodsaak van 'n karakteropvoedingsprogram binne kollegeverband in die Noordwes-provinsie: Verkenning en voorlopige voorstelle (Values and the need for character building programmes in the context of colleges in the North-West Province: Exploration and initial suggestions)', Koers of colleges in the North-West Province: Exploration and in
$76(3), 577-598$. https://doi.org/10.4102/koers.v76i3.43

Freeks, F.E., 2011c, Fatherhood training and equipping manual for fathers: Dad becoming fully you, Ivyline Technologies, Potchefstroom.

Freeks, F.E., 2013, Dad is destiny: The man God created to be, Ivyline Technologies, Potchefstroom.

Freeks, F.E., 2016a, 'Die noodsaak van Skrifgefundeerde vaderskap as antwoord op die voortslepende probleem van vaderskapafwesigheid in Suid-Afrika (The need for scripture-based fatherhood as the answer to the leading problem of father absenteeism in South Africa)', Tydskrif vir Christelike Wetenskap 52(1\&2), 1-27.

Freeks, F.E., 2016b, 'Youth intervention through training and equipping in the midst of challenges and crisis: The LIFEPLAN ${ }^{\circledR}$ programme as a possible solution', Missionalia 44(2), 205-223. https://doi.org/10.7832/44-2-150

Freeks, F.E., 2017a, 'Responding to the challenge of father absence and fatherlessness in the South African context: A case study involving concerned fathers from the North-West Province', Stellenbosch Theological Journal 3(1), 89-113. https://doi. org/10.17570/stj.2017.v3n1.a05

Freeks, F.E., 2017b, 'Responses of adolescents regarding the indispensable role of the Christian father as mentor within the family: A qualitative study', In die Skriflig 51(1), a2255. https://doi.org/10.4102/ids.v51i1.2255

Freeks, F.E., 2017c, 'A pastoral-theological view on the fundamental role of the father in variance with contemporary family structures and its adverse challenges for fatherhood: A literature review', Journal for Christian Scholarship 53(3\&4), 177-192.

Freeks, F.E., 2018a, 'Views of mothers on the fundamental role of the Christian father as mentor in a nuclear family environment', In die Skriflig 52(1), a2365. https:// doi.org/10.4102/ids.v52i1.2365

Freeks, F.E., 2018b, 'A missional evaluation of the LIFEPLAN ${ }^{\circledR}$ training and equipping programme for youth in rural areas. A case study of its impact in the Christiana district of South Africa', PhD thesis, North-West University, Potchefstroom.

Freeks, F.E., 2019, 'Die probleem van vaderafwesigheid in Suid-Afrika vanuit Bybelse riglyne (The problem of father absenteeism in South Africa from a biblical perspective)', Tydskrif vir Geesteswetenskappe 59(4), 1-16. https://doi.org/ 10.17159/2224-7912/2019/v59n4a17

Freeks, F.E., Greeff, M. \& Lotter, G.A., 2015a, 'Views of Christian fathers of their role as mentors in the transmission of values within the family context', Journal for Christian Scholarship 51(1), 21-45.

Freeks, F.E., Strydom, C. \& Bartlett, E., 2015b, 'Die impak van afwesige vaders op adolessente dogters se psigososiale welstand '[The impact of absent fathers on the psychological wellbeing of adolescent daughters]', Health SA Gesondheid 20(1), 45-89. https://doi.org/10.1016/j.hsag.2015.03.002

Freeks, F.E. \& Lotter, G.A., 2009, "n Prakties-teologiese ondersoek na die uitwerking van afwesige Vaders: ' $n$ verkennende kwalitatiewe ondersoek in die Promosagemeenskap (A practical theology investigation into the solution to absen fathers: An exploratory qualitative study in the Promosa community)', Koers 74(3), 519-534. https://doi.org/10.4102/koers.v74i3.136 
Freeks, F.E. \& Lotter, G.A., 2014, 'Possible "mentoring" and discipleship in the New Testament: A proposition', Journal for Christian Scholarship 50(3), 191-212.

Joubert, D., 1986, Waardes: Navorsing, metodologie en teorie, ondersoek en navorsingsmetodologie, Raad vir Geesteswetenskaplike Navorsing (Navorsingsverslaereeks 2), Pretoria.

Lepholletse, A.M.M., 2008, 'Teacher's influence on the value-orientation of learners in secondary schools', PhD thesis, North-West University, Potchefstroom.

Levtov, R., Van der Gaag, N., Greene, M., Kaufman, M. \& Barker, G., 2015, State of the world's fathers: Executive summary: A mencare advocacy publication, Promundo, Rutgers, Save the Children, Sonke Gender Justice, and the MenEngage Alliance, Washington, DC

Londt, M.P., Kock, M. \& John-Langba, J., 2017, 'The effects of biological fathers' incarceration on adolescent children and the challenges of absentee biological
fathers', Acta Criminologica: Southern African Journal of Criminology 30(4), 145-158.

Makou, G., Skosana, I. \& Hopkins, R., 2017, Factsheet: The state of South Africa's incarcerated places, viewed 13 August 2018, from https://africacheck.org/ factsheets/factsheet-the-state-of-south-africas-incarceratedplaces/.

Matlakala, F.K., Makhubele, J.C., Sekgale, I.L. \& Mafa, P., 2019, 'Perspectives of single mothers on the socio-emotional and economic influence of "Absent Fathers" in a child's life: A case study of rural community in South Africa', Journal of Socia Sciences and Humanities 16(4), 1-12.

Meyer, J., 2018, 'Restructuring the Christian fatherhood model: A practical theological investigation into the "male problematic" of father absence, HTS Teologies Studies/Theological Studies 74(1), 4870. https://doi.org/10.4102/hts.v74i1.4870

News24, 2013, SA has most inmates in Africa, viewed 13 August 2018, from https:// www.news24.com/SouthAfrica/News/SA-has-most-inmates-in-Africa-20130304.

Nimmo, P.T., 2007, Being in action: The theological shape of Barth's ethical vision, T \& T Clark, London.

Pekel-Uludagli, N., 2019, 'Are uninvolved fathers really incompetent and unsatisfied? Testing the mediator role of the father involvement from fathers' perspectives', European Journal of Development Psychology 16(5), 538-551. https://doi.org/10. European Journal of Development

Peyper, E., De Klerk, W. \& Spies, R., 2015, 'Experiences of young adult women with emotionally absent fathers', Journal of Psychology in Africa 25(2), 127-133. https//doi.org/10.1080/14330237.2015.1021513

Popenoe, D., 1996, 'A world without fathers', Wilson Quarterly 20(2), 12-16.

Salami, I.A. \& Okeke, C.I.O., 2018, 'Absent fathers' socio-economic status and perceptions of fatherhood as related to developmental challenges faced by children in South Africa', South African Journal of Childhood 8(1), 1-7. https://doi. org/10.4102/sajce.V8i1.522

Sieber, D., 2008, 'Engaging absent fathers in the treatment of children', Clinical Social Work 36(4), 333-340. https://doi.org/10.1007/s10615-008-0158-0

Staples, R., 1999, The black family, Wadsworth Publishing, Belmont, CA.
Theron, P.M., 2008, 'Equipping Christians living in an "unequally yoked" context', PhD thesis, North-West University, Potchefstroom Campus.

Van der Walt, B.J., 1999, Visie op die werklikheid, die bevrydende krag van 'n Christelike lewensbeskouing en filosofie, Noordwes-Universiteit, Potchefstroom.

Van der Walt, B.J., 2008, The eye is the lamp of the body: Worldviews and their impact, The Institute for Contemporary Christianity in Africa, Potchefstroom.

Van der Walt, B.J., 2010, At home in God's word: A transforming paradigm for being human and for social involvement, The Institute for Contemporary Christianity in Africa, Potchefstroom.

Van Wyk, W.C., 1996, 'Christelike norme en waardes in onderwys en opleiding', referaat aangebied by Afrikaanse Onderwyskongres: Onderwys en Opleiding en Toekomsperspektief, Bloemfontein, 16 Junie 1995.

Vaughan, J., 2010, Dads and the daughters they love, viewed 26 May 2019, from https:// www.focusonthefamily.ca/parenting/fatherhood/dads-and-the-daughters-theylove.

Veltman, N., 2018, email, 27 July, Welcome to Potchefstroom Correctional Centre History, Nicolaas.Veltman@dcs.gov.za

Veltman, N., 2020, email, 11 May, Welcome to Potchefstroom remand detention facility: History, Nicolaas.Veltman@dcs.gov.za

Vorster, J.M., 2004, Ethical perspectives on human rights, Potchefstroom Theological Publications, Potchefstroom.

Vorster, J.M., 2007, Christian attitude in the South African liberal democracy, Potchefstroom Theological Publications, Potchefstroom.

Vorster, J.M., 2008a, "n Christelike perspektief op menswaardigheid [A Christian perspective on human dignity]', Dutch Reformed Theological Journal 49(1\&2), 195-205.

Vorster, J.M., 2008b, The challenge of contemporary religious fundamentalism, Unisa Press, Pretoria.

Waresak, J.T., 2016a, 5 keys to lead your wife, i.e. wear the pants, viewed 26 May 2019, from https://www.drjamesdobson.org/blogs/the-fatherhood-challenge/the fatherhood-challenge/2016/06/22/5-keys-to-lead-your-wife-ie-wear-the-pants.

Waresak, J.T., 2016b, Missional fatherhood, viewed 26 May 2019, from https://www. driamesdobson.org/blogs/the-fatherhood-challenge/the-fatherhood-challenge/ 2013/11/11/missional-fatherhood.

Williams, R.B., 2014, 'The male identity crisis and the decline of fatherhood', Psychology Today, viewed 26 May 2019, from https://www.psychologytoday. $\mathrm{com} / \mathrm{em} / 152400$.

Wood, P. \& Brownhill, S., 2018, “'Absent fathers", and children's social and emotional learning: An exploration of the perceptions of "positive male role models" in the primary school sector', Gender and Education 30(2), 172-186. https://doi.org/10. 1080/09540253.2016.1187264 